\title{
Evaluation of Skill-based Questions According to Science Education Teachers in Turkey
}

\author{
Ahmet Volkan Yüzüak ${ }^{1 *}$, Recep Recepkethüda² \\ ${ }^{1}$ Department of Educational Sciences, Faculty of Education, The University of Bartın, Bartın, Turkey, ${ }^{2}$ Department of Educational Sciences, Ministry \\ of National Education, Ankara, Turkey
}

*Corresponding Author: volkanyuzuak@bartin.edu.tr

\section{ABSTRACT}

This study aimed to determine science teachers' opinions about the skills-based questions (SBQs) used in Turkey's high school's entrance exam. In this study, the phenomenology method was used. The study consisted of 15 participants working as science teachers with at least 5 years of professional experience in public schools in different provinces during the 2020-2021 academic years. The study data were collected through the semi-structured interview form prepared by the study's researchers. The form included three questions related to the participants' demographics and another 12 on SBQ. Content analysis was used by help of MAXQDA 20 to analyze the data. The study findings revealed that SBQ and lectures in textbooks were incompatible and books still offered traditional-type questions. Remarkably, science education is the most appropriate course to create SBQ. The teaching methods used in lectures should be associated with high-level thinking skills. Teachers need workshops related to SBQ. Therefore, this study has proposed that textbook contents be revised, and teachers be informed accordingly.

KEY WORDS: Science education; high school entrance exam; skill-based questions

\section{INTRODUCTION}

L earning plays an essential role in schools and every step of life. Current knowledge is changing rapidly and may lose its status. Thus, individuals must know how to access information, distinguish between correct and incorrect information, and apply it in daily life (Fer, 2014). Memory directly affects the information that is learned. Learning can be defined as the process of detecting, recording, remembering, and using information. The process is active, and the data can become permanent and meaningful when individuals work with desire, effort, and awareness (Ausubel, 1968).

Researchers have used measurement and assessment to evaluate if learning or objectives are achieved. Deficiencies are found, and learning is guided once the studies related to measurement and assessment are valid and credible (Başol, 2019). The Turkish Ministry of National Education (MoNE) has changed the science curriculum, central exams, and school levels transition. The exam and selection process for the transition to secondary education in Turkey started in 1955 at Maarif colleges (now called Anatolian High Schools). In 1997, with the surge in high school numbers, the high school entrance exam (HSEE) began being implemented. In 2005, this exam was re-named Secondary Education Entrance Exam (SEEE, in Turkish OKS). In 2009, another exam to determine students' learning level was conducted. In 2013, the Transition from Basic Education to Secondary Education (TBESE, in Turkish TEOG) exams took place. Then, in 2017, a new system was introduced based on $90 \%$ address and $10 \%$ selected with HSEE. The commonality across all these exams is that they all include multiple-choice questions (At1lgan, 2018). Social, cultural, and economic reasons, as well as the results of international exams such as Programme for International Student Assessment (PISA), Trends in International Mathematics and Science Study (TIMSS), Progress in International Reading Study (PIRLS), might bear such changes (MoNE, 2005, 2015, 2017, and 2018a). Similarly, Turkey's and other countries' education systems have been restructured (Bonal and Tarabini, 2013; Harus and Davidovitch, 2019; Woessmann, 2018).

Turkey has regularly participated in PISA since 1999 (excluding 2003) and took part in PIRLS in 2001. The effects of the exam results on education were analyzed (Gür et al., 2012). The problematical areas were specified, and solutions were proposed as new objectives (MoNE, 2019a). From this viewpoint, reducing the number of exams applied was the medium-term goal of students' admission to high schools and university, a path that complies with Turkey's 2023 vision. As part of this vision, the exams will be reorganized in purpose, question types, content, and benefits. The new arrangement has started to provide high level and critical thinking skills (MoNE, 2018a). MoNE has focused on two objectives in the transition of exams. The first objective is to eliminate the exam requirement for every student, make an address-based placement, and create a system for students eager to go to the high schools accepting with HSSE. The second objective is to make Turkish students more successful in international 
exams by differentiating the question content and format. However, a significant difference in success exists between high schools accepting students with HSSE and addressbased high schools. This forces students to enter exams. Students taking exam was $81.46 \%$ in 2018 and $85.08 \%$ in 2019 (MoNE, 2018b, 2019b).

Some updates for the exam system are as follows. The effect of each part on the overall exam score has been changed. Mathematics, Science, Turkish Language, History of Revolution, Religious Culture and Moral Knowledge, and English are conducted in two sessions: numerically and verbally. The time for the numerical part is $80 \mathrm{~min}$ and $75 \mathrm{~min}$ for the verbal part. There are twenty questions in Turkish, Mathematics, and Science each, and the coefficient of each question is four. There are ten questions in History of Revolution, English, and Religious Culture and Moral Knowledge each and the coefficient of each question is one (MoNE, 2018b, 2019b). The coefficient of Turkish, Mathematics, and Science are usually higher than those in national and international exams, so the classes are essential for the total score. For example, questions of PISA, initiated in 2000, are based on understanding, evaluating, detailedthinking, problem-solving skills, reasoning, scientific questioning, and interpretation (OECD, 2019). The second update is skill based questions (SBQ) for HSEE. SBQ allow students to learn, interpret, and draw conclusions without memorizing information or formulas. Hence, students will be able to use analytical and critical thinking in their life (Zorluoğlu et al., 2020). With these updates, the aim was to heighten the success in international exams (Selçuk, 2019). Therefore, the question format for PISA and TIMMS is essential, and they set an example for us (Çepni, 2019). The General Directorate of Measurement and Evaluation services has shared SBQ samples in this context. In addition, MoNE tried to remove the uncertainty by publishing and sharing sample questions every month (MoNE, 2018a). The 2018 exam questions were different from those of the TBESE Exam, but they resembled the PISA exam question format (Güler and Ülger, 2018). MoNE prepared SBQ concerning objectives to measure students' skills in understanding, interpreting and questioning, problem-solving, and critical thinking (MoNE, 2018c).

The changes or updates for the exam system and question format have caused uncertainty among students and teachers (Gün and Kaya, 2018). By reviewing these exams, it was seen that there were many blank questions in mathematics and science in 2018. Students needed extra time to answer the SBQ. Thus, the exam duration was extended from $75 \mathrm{~min}$ to $80 \mathrm{~min}$ in 2019 (MoNE, 2018b). The 2019 exam results indicated that the rate of blank questions had diminished. The ratio of blank math questions to all questions was $42.89 \%$ in 2018 and was $40.28 \%$ in 2019 . The ratio of blanked science questions stood at $14.17 \%$ in 2018 and $10.02 \%$ in 2019 . Extending the exam time worked (MoNE, 2019b).
The weighted scores of Turkish, Mathematics, and Science courses were more effective in specifying student success (MoNE, 2019c). Mathematics questions evaluated the ability to understand, analyze and associate them with daily life and reading comprehension (Aksoy et al., 2020). It was observed that mathematics questions had been $74 \%$ more effective in measuring problems, associating with subjects, reasoning, and questioning (Güler et al., 2018). The Turkish questions in the HSEE were similar to those in PISA. They were open to interpretation and could be associated with daily life and reasoning (Batur et al., 2019).

Teachers from each discipline must be asked for opinion during the preparation process of SBQ since teachers are responsible for implementing the current curriculum (Levine, 1995). SBQ should be compatible with the textbook contents (ERG, 2019; Kutlu, 2018). The teachers use course objectives and teaching methods. SBQ contribute to developing high-level learning skills, and teachers have to become familiar with the steps of preparing, applying, and evaluating SBQ.

This study aimed to determine science teachers' opinions about the SBQ in the HSEE. The results will contribute to the development of the studies on SBQ. This research also sought answers to the following:

1. What are teachers' opinions about textbook content, course objectives and SBQ?

2. What are teachers' opinions about the contribution of SBQ to students' academic achievement, interest, and development of their skills in science teaching?

3. What are teachers' opinions about the teaching method and SBQ?

4. What are teachers' opinions about the necessity of inservice training related to the preparation, implementation, and evaluation of SBQ?

\section{METHODOLOGY}

The research was designed using qualitative method. Phenomenology, used in this study, aims to learn more about known but undetailed phenomena (Creswell and Poth, 2016; Yıldırım and Şimşek, 2018). This method, allowing thorough research on phenomena, provides a rich interpretation and helps students reach very different ideas (Mayring, 2004). Phenomenology study reveals how people perceive and explain their experiences (Creswell, 2002; Patton, 2014).

\section{Participants}

In phenomenological studies, participants experiencing this phenomenon are chosen (Baker et al., 1992). Therefore, this study sought to include science teachers working in public schools. The reason for selecting these teachers is that the science textbook being used is standard. In addition, the SBQ application time is considered, and the science teachers have at least 5 years of professional experience and are all $8^{\text {th }}$-grade teachers. A semi-structured interview form was prepared and used to collect the study data. Teachers participate in interviews as the data collection voluntarily. 
For this reason, researchers of this study favored purposeful sampling.

The size of the study group is essential for the data obtained (Baltac1, 2018). If the researcher works in the subject field, it becomes easier to see the study group's understanding, conduct the interview and access the relevant data (Maggs-Rapport, 2000). By the ethical research rules (Bartın University Protocol Number: 2021-SBB-0344 Decision Date: 14.09.2021 Meeting Number: 14), the teachers were classified as ST1, ST2,... ST15. The science teachers taking part in the study were analyzed by career length. The shortest career length among teachers was 6 years (ST13). The longest one was 24 years (ST11). The average was found 13.73 years.

\section{Data Collection}

A researcher is a critical element in creating and collecting data in qualitative research (Wolcott, 1975). The study data were obtained through a semi-structured interview form titled "Evaluation of SBQ according to Teacher Opinions of Science Teachers" that the researchers had prepared. The interviews were held in the form of conversations and mutual communication-enabled negotiations (Davis, 1990). The data came from science teachers working in the 2020-2021 academic year with $8^{\text {th }}$-grade students.

The semi-structured interview form includes open-ended questions designed to determine science teachers' opinions about SBQ. The interview form consisted of three items to assess the demographic characteristics of the working group and a total of twelve items aimed for the four sub-problems of this study.

\section{Data Analysis}

Content analysis, one of the existing qualitative methods in the meaningful interpretation of data (Schreier, 2012), was used in this study. It allows for a detailed data examination and has a systematic structure to identify and measure facts (Downe-Wamboldt, 1992; Yıldırım and Şimşek, 2018). Successfully applied content analysis is based on separate concepts describing the phenomenon of the study in themes and codes (Cavanagh, 1997; Elo and Kyngäs, 2008; Hsieh and Shannon, 2005).

\section{Credibility and Validity}

It is challenging to conduct credibility and validity studies in qualitative research. Since it does not have numerical data, determining credibility and validity are different from that of quantitative analysis. Reliability and validity in qualitative studies are related to the study's credibility. On the other hand, credibility can be achieved by the realization of quadrilacy, credibility, transferability, and affirmability. Qualitative research's credibility is specified with the description of all study processes, the clearness of the data obtained the correct determination of the working group and the size of the group (Başkale, 2016). Credibility and validity in qualitative research are the knowledge and skill of the researcher who has carried out the study (Pyett, 2003).

\section{Findings}

The code map of qualitative data from the content analysis was obtained using Maxqda 20. Four main themes were determined: "compatibility," "contribution," "teaching methods," and "in-service training." The related themes and codes are shown in Figure 1.

\section{Findings related to the first sub-problem}

The frequency and distributions by the subcodes of the "compatibility-textbook" are indicated in Table 1.

The science teachers opinions about the compatibility of textbooks with SBQ are as follows:

- ST5: "I don't think there's a science course subject related to $S B Q$ "

- ST7: "Textbooks are not suitable for $S B Q$. They are incomplete"

- ST10: "Unfortunately, the science course subject and end-of-unit evaluation questions in the textbooks are incompatible with $S B Q$ "

- ST11: "The subject narration of the topics in the textbooks sent by the MoNE is not prepared in line with SBQ."

Science teachers' opinions about "not suitable" subcode and "not suitable for developing high-level skills" are as follows:

- ST3: "There is no course subject related to developing high-level skills in textbooks.

When the findings mentioned above are evaluated, it can be stated that science teachers think course textbook content was insufficient considering SBQ. Findings of the compatibility of the textbook questions with the SBQ and concentrated questions come from science teachers' opinions. The frequency and percentage distribution of the "questions on textbooks" code are shown in Table 2.

Science teachers' opinions about the questions in textbooks are "traditional" and "not suitable for SBQ":

- ST1: "There are short-answered questions in textbooks that are not compatible with SBQ"

- ST6: "There are more traditional questions in the textbook. Fill in the blanks, match the classic question and so on. In other words, it is almost completely incompatible with exam questions"

- ST14: "The evaluation questions of textbooks are not suitable for the next generation. They are not skill-based"

- ST10: "Certainly, the questions in the textbook are traditional-style questions. There is no relation with $S B Q "$

- ST7: "There is insufficient relation between questions in textbooks and SBQ."

Examples for other subcodes are as follows:

- ST4: "There are usually 8 or 10 classic open-ended questions in the evaluations, and then there are fill in the blanks, right-wrong questions. For the test part, there are $S B Q$. But I don't think they are enough"

- ST12: "I don't think there's been any change in the question types in the textbooks. The evaluation questions 


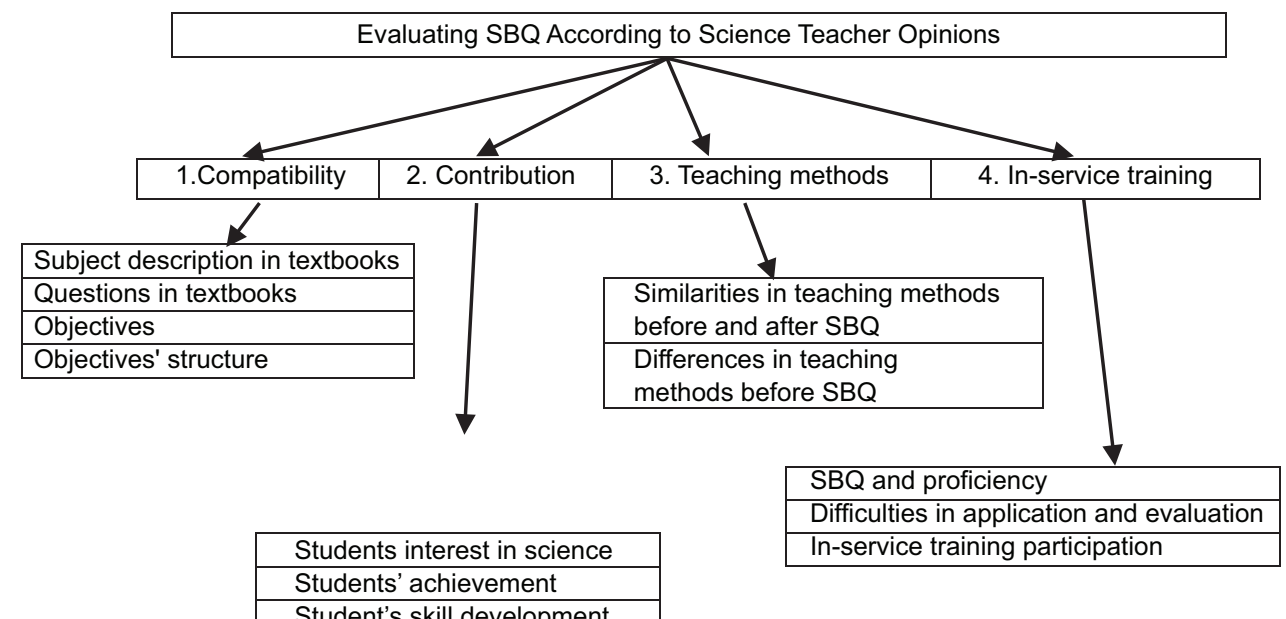

Figure 1: Code map related to skills-based questions

\begin{tabular}{|c|c|c|c|c|}
\hline Theme & Codes & Subcodes & Frequency & Percent \\
\hline \multirow[t]{8}{*}{ Compatibility } & \multirow{8}{*}{$\begin{array}{l}\text { Subject } \\
\text { description } \\
\text { in textbooks }\end{array}$} & Not suitable & 8 & 50.00 \\
\hline & & $\begin{array}{l}\text { Experiments are } \\
\text { suitable }\end{array}$ & 2 & 12.50 \\
\hline & & Suitable & 1 & 6.30 \\
\hline & & $\begin{array}{l}\text { Superficial } \\
\text { information }\end{array}$ & 1 & 6.30 \\
\hline & & $\begin{array}{l}\text { Not suitable for } \\
\text { development of } \\
\text { high-level skills }\end{array}$ & 1 & 6.30 \\
\hline & & $\begin{array}{l}\text { Experiments are } \\
\text { not suitable }\end{array}$ & 1 & 6.30 \\
\hline & & $\begin{array}{l}\text { No need to } \\
\text { change }\end{array}$ & 1 & 6.30 \\
\hline & & $\begin{array}{l}\text { Preparatory } \\
\text { questions are } \\
\text { appropriate }\end{array}$ & 1 & 6.30 \\
\hline Sum & & & 16 & 100.00 \\
\hline
\end{tabular}

lead to understanding and remembering information only. We don't see any creative thinking questions or others that will trigger the child's imagination."

When the findings above are evaluated, it can be said that science teachers think the questions in the textbooks did not fit SBQ. The questions in the textbook were about knowledge comprehension. They were based on memorization and consisted of question types, such as short-answer, open-ended, true-false, and matching questions. The questions were primarily in the traditional style. The frequency and rate distribution of the "objectives" code are demonstrated in Table 3.

Science teachers' opinions about the compatibility of SBQ to the course objectives are as follows:

- ST8: "There are hardly any SBQ in textbooks"

- ST9: "SBQ are very few"

- ST11: "SBQ rarely included in textbooks are suitable for measuring objectives"
Table 2: Teacher's opinions about the compatibility SBQ with questions and the types in textbooks

\begin{tabular}{lllcc}
\hline Theme & Codes & Subcodes & Frequency & Percent \\
\hline Compatibility & $\begin{array}{l}\text { Questions } \\
\text { in textbooks }\end{array}$ & Traditional & 11 & 28.21 \\
& & Not suitable for & 7 & 17.95 \\
& SBQ & & \\
& Based on & 5 & 12.82 \\
& knowledge level & & \\
& SBQ are few & 3 & 7.69 \\
& Comprehension & 3 & 7.69 \\
& Fill in the blank & 2 & 5.13 \\
& Superficial & 2 & 5.13 \\
& Open-ended & 1 & 2.56 \\
& Based on & 1 & 2.56 \\
& memorization & & \\
Remembering & 1 & 2.56 \\
& Short answer & 1 & 2.56 \\
& questions & & \\
Right-wrong & 1 & 2.56 \\
& questions & & \\
Matching & 1 & 2.56 \\
& & 39 & 100.00 \\
\hline
\end{tabular}

SBQ: Skills-based questions

- ST1: "There are no SBQ in textbooks, and in existing ones, they are suitable for objectives"

- ST4: "SBQ usually compete with objectives"

- ST6: "They are fully compatible with the objectives."

Science teachers state that SBQ are not sufficient in number in textbooks, but they think the present SBQ align with course objectives.

The science teachers were asked: "What do you think about the suitability of course objectives and creating SBQ?" The frequency and percentage distributions of "objectives' structure" and SBQ are shown in Table 4.

Science teachers have agreed that course objectives' structure and SBQ are compatible. Some goals are appropriate for 
traditional question types, and some are appropriate for SBQ. Science teachers' opinions about the compatibility of SBQ with science objectives' structure are as follows:

- ST1: "SBQ lead students to think and interpret analytically. Science course includes interpreting events in daily life and experiments. Therefore, science course is appropriate for $S B Q$ "

- ST2: "I think $S B Q$ and objective are compatible, and science is the most appropriate course for SBQ"

- ST4: "I think the objectives are appropriate because science leans on daily life and experiments".

\section{Findings related to second sub-problem}

The sub-codes of "contribution" themes are "student interest in science teaching," "student achievement," and "student skill development." The frequency and percentage distributions of the "student interest in science teaching" subcode obtained are indicated in Table 5.

Science teachers' opinions about the "student interest in science teaching" are as follows:

- ST5: "The new exam includes $S B Q$, and it reduces the interest of many students since $S B Q$ are challenging among students"

- ST12: "The SBQ is always a difficult one for students. I mean, students biased about it. They believe without reading that the questions $S B Q$ are hard to answer. Their interest diminishes overall"

- ST13: "The questions are visually longer; students are biased about the $S B Q$, and they think $S B Q$ are difficult"

Table 3: Teacher opinions about the compatibility SBQ and objectives

\begin{tabular}{lllcc}
\hline Theme & Codes & Subcodes & Frequency & Percent \\
\hline Compatibility & Objectives & $\begin{array}{l}\text { Suitable for } \\
\text { objectives }\end{array}$ & 11 & 61.10 \\
& & $\begin{array}{l}\text { Number of SBQ } \\
\text { are not enough }\end{array}$ & 4 & 22.20 \\
& No SBQ & 3 & 16.70 \\
Total & & 17 & 100.0 \\
\hline
\end{tabular}

SBQ: Skills-based questions

Table 4: Teachers' opinions about the compatibility of SBQ with science objectives' structure

\begin{tabular}{lllcc}
\hline Theme & Codes & Subcodes & Frequency & Percent \\
\hline Compatibility & $\begin{array}{l}\text { Objectives' } \\
\text { structure }\end{array}$ & Suitable for SBQ & 5 & 31.25 \\
& $\begin{array}{l}\text { More Suited to } \\
\text { SBQ }\end{array}$ & 4 & 25.00 \\
& $\begin{array}{l}\text { Some objectives } \\
\text { are traditional } \\
\text { Some objectives }\end{array}$ & 3 & 18.75 \\
& $\begin{array}{l}\text { are suitable } \\
\text { Suitable for both }\end{array}$ & 2 & 12.50 \\
& & 16 & 12.50 \\
Total & & & \\
\hline
\end{tabular}

SBQ: Skills-based questions
- ST3: "SBQ are too long. They require critical thinking skills and science reasoning skills. Some students may challenge science education"

- ST1: "SBQ depend on interpretation, and they draw students' attention"

- ST15: "I think that science course is based on application, and it affects positively."

The science teachers have stated that SBQ are complicated and lengthy, and students develop biased attitudes. Thus, some students have difficulty understanding what they are reading. Their interest falls. On the other hand, students' appeal to advanced interpretive skills has grown. Significantly, some teachers have expressed no link between students' interests and SBQ. The frequency and percentage distributions of the "students' achievement" subcode obtained are presented in Table 6 .

Science teachers' opinions about the "students' achievement" are as follows:

- ST15: "Positive for students who can interpret or learn to associate information"

- ST2: "Teachers want students to comprehend, apply, synthesize and analyze $S B Q$. I think $S B Q$ increase the ability to solve problems rather than achieve, which will positively affect students' achievement"

- ST3: "SBQ allow students to think along many aspects of an event so that they can do reasoning. I think all these will boost students' success"

- $\quad$ ST6: "There has certainly been an increased achievement in science education recently. The main reason for this is are the $S B Q$, which require the student to produce rational solutions rather than memorization"

- ST9: "Some students think $S B Q$ are hard to solve. Therefore, their interest in science education drop."

Science teachers have expressed that SBQ improves interpretation and students' high-level thinking skills and

Table 5: Frequency and percentage distribution of subcodes belonging to student interest code in science teaching

\begin{tabular}{lllcc}
\hline Theme & Codes & Subcodes & Frequency & Percent \\
\hline Contribution & Student & SBQ are difficult & 6 & 19.30 \\
& interest & Interest increasing & 6 & 19.35 \\
& in & Interest decreasing & 4 & 12.90 \\
& science & Exposition & 3 & 9.68 \\
& teaching & SBQ don't affect & 2 & 6.45 \\
& & interest & & \\
& & Daily life & 2 & 6.45 \\
& Prejudice & 2 & 6.45 \\
& Application & 2 & 6.45 \\
& & Understanding & 1 & 3.23 \\
& & Critical skill & 1 & 3.23 \\
Total & The Problem is long & 1 & 3.23 \\
\hline SBQ: & Experiment & 1 & 3.23 \\
& & 31 & 100.00 \\
\hline
\end{tabular}

SBQ: Skills-based questions 


\begin{tabular}{|c|c|c|c|c|}
\hline Theme & Codes & Subcodes & Frequency & Percent \\
\hline \multirow[t]{7}{*}{ Contribution } & $\begin{array}{l}\text { Students' } \\
\text { achievement }\end{array}$ & $\begin{array}{l}\text { Positive impact } \\
\text { on achievement }\end{array}$ & 7 & 29.17 \\
\hline & & $\begin{array}{l}\text { Negative impact } \\
\text { on achievement }\end{array}$ & 7 & 29.17 \\
\hline & & High-level & 5 & 20.83 \\
\hline & & Exposition & 2 & 8.33 \\
\hline & & Daily life & 1 & 4.17 \\
\hline & & $\begin{array}{l}\text { Decreasing } \\
\text { interest }\end{array}$ & 1 & 4.17 \\
\hline & & $\begin{array}{l}\text { No impact on } \\
\text { achievement }\end{array}$ & 1 & 4.17 \\
\hline Total & & & 24 & 100.00 \\
\hline
\end{tabular}

enable students to associate the questions with daily life. They think SBQ increase students' achievement. On the other hand, SBQ may lessen the interest in the course, too. The frequency and percentage distributions of the "students" skills development" subcode obtained are presented in Table 7.

Science teachers' opinions about the "students' skills development" are as follows:

- ST2: "Students began to feel more confident about $S B Q$. It's now easier to solve problems in daily life. We can say students' problem solving, synthesizing, analysis, and interpretation skills have improved"

- ST10: "By removing memorization, their ability to comprehend and comment has improved"

- ST14: "Reading comprehension, interpretation, adaptation of knowledge into the question has improved"

- ST1: "Children's ability to interpret, comment, perform analytical thinking and analysis, handle daily events contribute to improving thinking skills"

- ST13: "I think it is useful to give the students the ability to think at a higher level to realize the steps of scientific thinking"

- ST9: "I can say the reading and comprehension skills of the students have improved."

Science teachers express that SBQ improve skills, such as interpreting, reading ability, analysis, comprehension skills, highlevel thinking, problem-solving, production, design, synthesis, knowledge, application, analytical thinking, and comprehension.

\section{Findings related to third sub-problem}

The sub-codes of "teaching method" themes are "similarities in teaching methods before SBQ" and "differences in teaching methods before SBQ." The frequency and percentage distributions of the "similarities in teaching methods before $S B Q$ " subcode obtained are presented in Table 8.

Science teachers' opinions about the "similarities in teaching methods before $S B Q$ " are as follows:

- ST1: "We generally use the lecturing method. We also use experiments and demonstration methods. We have
Table 7: Frequency and percentage distribution of subcodes for student's skill development

\begin{tabular}{lllcc}
\hline Theme & Codes & Subcodes & Frequency & Percent \\
\hline Contribution & Student's skill & Exposition & 4 & 16.67 \\
& development & Reading ability & 3 & 12.50 \\
& & Analysis & 3 & 12.50 \\
& & Comprehension & 3 & 12.50 \\
& skills & & \\
& High-level & 2 & 8.33 \\
& Problem & 2 & 8.33 \\
& solving & & \\
& Producing & 1 & 4.17 \\
& Design & 1 & 4.17 \\
& Synthesis & 1 & 4.17 \\
& Knowledge & 1 & 4.17 \\
& Application & 1 & 4.17 \\
& & Analytical & 1 & 4.17 \\
& thinking & & \\
& Comprehension & 1 & 4.17 \\
& & 24 & 100.00 \\
\hline
\end{tabular}

not changed the teaching methods; we just change the problem-solving strategy for SBQ"

- ST2: "We usually conduct experiments before and after using $S B Q$. After $S B Q$, the traditional method is used"

- ST3: "I almost use the same teaching methods, such as lecturing, experimentation, demonstration. I still use them"

- ST4: "The lecturing method is a must. Although we express that we conduct experimentation, we use the lecturing method"

- $\quad$ ST9: "I use the same methods before and after $S B Q$, i.e., lecturing, demonstration, brainstorming."

Science teachers usually use the lecturing method. Mainly, they use such teaching methods as experimentation demonstration. The frequency and percentage distributions of the "differences in teaching methods before $S B Q$ " subcode obtained are presented in Table 9.

Science teachers" opinions about the "differences in teaching methods before $S B Q$ " are as follows:

- ST1: "Before $S B Q$, short-answered questions were necessary. We did not use experimentation due to limited time. But now, experimentation and activities related to explication have become more critical"

- ST11: "We focus more on the relationship between cause and effect, instead of question and answer."

Findings related to fourth sub-problem

The sub-codes of "in-service training" are as follows:

- "SBQ and proficiency"

- "Difficulties in application and evaluation"

- "In-service training and participation."

The frequency and percentage distributions of the "SBQ and qualification" subcode obtained are presented in Table 10. 
Science teachers' opinions about the "SBQ and qualification" are:

- ST1: "I have not prepared SBQ, and I do not know exactly how to prepare them. I am not enough to prepare them"

- ST2: "I have not prepared SBQ. I don't feel good enough to prepare because I haven't done it before"

- ST3: "I have not done any work on preparing $S B Q$ so far. I am not enough to prepare $S B Q$ "

- ST6: "Even though I have the training to prepare $S B Q$, this job is tough, and I still have not reached that level"

- ST9: "I've never prepared one single SBQ. I also did not attend a training for this."

Science teachers stated they did not prepare SBQ and considered themselves sufficient to prepare questions. The frequency and percentage distributions of the "difficulties in application and evaluation" subcode obtained are presented in Table 11.

Science teachers' opinions about the "difficulties in application and evaluation" are as follows:

- ST4: "Time for the exam is $40 \mathrm{~min}$. $S B Q$ are too long. Thus, the exam will include a maximum of $2 S B Q$ "

Table 8: Frequency and percentage distribution of subcodes of similarities in teaching methods before and after SBQ

\begin{tabular}{lllcc}
\hline Theme & Codes & Subcodes & Frequency & Percent \\
\hline Teaching & $\begin{array}{l}\text { Similarities } \\
\text { Method }\end{array}$ & Lecturing & 8 & 33.33 \\
& $\begin{array}{l}\text { methods before } \\
\text { and after SBQ }\end{array}$ & $\begin{array}{l}\text { Experimental } \\
\text { method }\end{array}$ & 6 & 25.00 \\
& & $\begin{array}{l}\text { Demonstration } \\
\text { Same methods } \\
\text { Questioning and } \\
\text { answering }\end{array}$ & 3 & 12.50 \\
& & $\begin{array}{l}\text { Observation } \\
\text { method }\end{array}$ & 1 & 12.50 \\
& & & 24 & 100.50 \\
Total & & & & \\
\hline
\end{tabular}

SBQ: Skills-based questions

Table 9: Frequency and percentage distribution of subcodes of the differences in teaching methods after SBQ

\begin{tabular}{lllcc}
\hline Theme & Codes & Subcodes & Frequency & Percent \\
\hline $\begin{array}{l}\text { Teaching } \\
\text { Method }\end{array}$ & $\begin{array}{l}\text { Differences } \\
\text { in teaching } \\
\text { methods } \\
\text { before SBQ }\end{array}$ & $\begin{array}{l}\text { Methods for } \\
\text { interpretation }\end{array}$ & 3 & 21.43 \\
& & $\begin{array}{l}\text { Experimental } \\
\text { method } \\
\text { Demonstration } \\
\text { Observation }\end{array}$ & 2 & 21.43 \\
& & Cause and effect & 1 & 14.29 \\
& & relationship & 14.29 \\
& & modeling & 7.14 \\
& & No difference & 1 & 7.14 \\
Research & 1 & 7.14 \\
Total & & 14 & 100.00 \\
\hline
\end{tabular}

SBQ: Skills-based questions
- ST8: "SBQ need time to implement. Therefore, the number of SBQ used during the course hours or written exams decreases. Since each student's cognitive development is not the same, some students can become unsuccessful. Some students have difficulty understanding such questions and finding the solutions"

- ST10: "The students had difficulty understanding the questions"

- ST9: "We have difficulty as students and teachers because the questions are difficult to understand"

- ST5: "Since there are different levels of students in the classrooms, we use traditional questions in the written exams and $S B Q$ in the courses for the students preparing for the HSEE. If we use $S B Q$ in written exams, it will decrease the average score of the exam. We have no problem with the evaluation."

Science teachers have also expressed that they have difficulty applying and understanding SBQ. They need more time.

Table 10: SBQ studies and frequency and percentage distribution of subcodes belonging to proficiency code

\begin{tabular}{lllcc}
\hline Theme & Codes & Subcodes & Frequency & Percent \\
\hline $\begin{array}{l}\text { In-Service } \\
\text { Training }\end{array}$ & $\begin{array}{l}\text { SBQ and } \\
\text { proficiency }\end{array}$ & $\begin{array}{l}\text { I didn't have a } \\
\text { study }\end{array}$ & 10 & 41.67 \\
& $\begin{array}{l}\text { I'm not enough } \\
\text { Trained in SBQ } \\
\text { preparation }\end{array}$ & 8 & 33.33 \\
& $\begin{array}{l}\text { Inadequate in } \\
\text { drawing and } \\
\text { visualizing }\end{array}$ & 1 & 4.17 \\
& $\begin{array}{l}\text { I'm good Enough } \\
\text { 2-3 questions } \\
\text { prepared } \\
\text { Trying to write } \\
\text { SBQ }\end{array}$ & 1 & 4.17 \\
Not at the desired & 1 & 4.17 \\
level & 1 & 4.17 \\
Total & & 24 & 100.00 \\
\hline SBQ: Skills-based questions & &
\end{tabular}

\begin{tabular}{|c|c|c|c|c|}
\hline Theme & Codes & Subcodes & Frequency & Percent \\
\hline \multirow{8}{*}{$\begin{array}{l}\text { In-Service } \\
\text { Training }\end{array}$} & \multirow{8}{*}{$\begin{array}{l}\text { Difficulties } \\
\text { in application } \\
\text { and evaluation }\end{array}$} & Time & 6 & 30.00 \\
\hline & & $\begin{array}{l}\text { Understanding the } \\
\text { question }\end{array}$ & 4 & 20.00 \\
\hline & & $\begin{array}{l}\text { No problem with } \\
\text { evaluation }\end{array}$ & 3 & 15.00 \\
\hline & & Lack of materials & 2 & 10.00 \\
\hline & & Students struggling & 2 & 10.00 \\
\hline & & $\begin{array}{l}\text { Deficiencies in } \\
\text { textbooks }\end{array}$ & 1 & 5.00 \\
\hline & & $\begin{array}{l}\text { Decreasing } \\
\text { achievement }\end{array}$ & 1 & 5.00 \\
\hline & & Lack of resources & 1 & 5.00 \\
\hline Total & & & 20 & 100.00 \\
\hline
\end{tabular}


The frequency and percentage distribution of the "in-service training and participation" subcode obtained is presented in Table 12.

Science teachers' opinions about the "in-service training and participation" are as follows:

- ST3: "I think in-service training on SBQ is necessary because there are no examples to guide us in curriculums. I think other teachers agree with me, and I would like to participate in in-service training"

- ST4: "I think that an education related to drawing string can be useful. I want to participate in in-service training"

- ST15: "I think it will be useful. I would like to participate"

- ST11: "Although I consider myself sufficient to prepare questions, I would like to participate in the in-service training that will open since I think in-service training plays an important role in developing educators"

- ST6: "I always want to participate in such training. Preparing questions exists at every stage of a teacher's life. Mini-test, trial or in writing. If we want to improve the quality of questions, the in-service training becomes necessary."

\section{DISCUSSION}

Works related to the cognitive domain were completed in the 1950s, and taxonomy, commonly referred to as Bloom's Taxonomy of the Cognitive Domain, was developed. The original levels are knowledge, comprehension, application, analysis, synthesis, and evaluation (Bloom et al., 1956). Remembering, understanding, and applying are categorized as lower order thinking skills while analyzing, evaluating, and creating are classified as higher order thinking skills (HOTS). The PISA assessment questions that test the students require HOTS, similar to the TIMSS assessment (OECD, 2019). SBQ includes HOTS. This research has found out the science teachers' opinions on SBQ.

The evaluation of science teachers' opinions related to SBQ has brought forward that the textbooks are not fully adaptive to SBQ, and there is a lack of compliance with the end-of-unit evaluation questions. Science gains are compatible with SBQ and that science gains are one of the most appropriate courses for creating SBQ. Furthermore, SBQ contribute positively to the development of students. Teachers preferred methods to interpret the processing of lessons and methods that include

\begin{tabular}{|c|c|c|c|c|}
\hline Theme & Codes & Subcodes & Frequency & Percent \\
\hline \multirow[t]{2}{*}{$\begin{array}{l}\text { In-Service } \\
\text { Training }\end{array}$} & $\begin{array}{l}\text { In-Service } \\
\text { Training } \\
\text { participation }\end{array}$ & $\begin{array}{l}\text { In-service } \\
\text { training } \\
\text { required and I } \\
\text { participate }\end{array}$ & 14 & 93.33 \\
\hline & & $\begin{array}{l}\text { Uncoded } \\
\text { Documents }\end{array}$ & 1 & 6.67 \\
\hline Total & & & 15 & 100.00 \\
\hline
\end{tabular}

research and cause and effect relationships. It is concluded that teachers need in-service training for the preparation, implementation, and evaluation of SBQ and they are eager to participate in in-service training.

This study has demonstrated that the subject expressions of science teachers in textbooks are not compatible with SBQ. Subject descriptions and questions consistent with the SBQ in the central exams should be covered in the textbooks (Fidan, 2018). The textbooks distributed by the Turkish MoNE do not contain subject narratives suiting SBQ, a situation which leads students to resort to extra resources. This situation creates a problem for economy and household budget (Akçay et al., 2017). For questions that require high-level thinking skills, such as SBQ, resources should be allocated to develop these skills (Ar1kan and Kırınd1, 2020). The teacher's opinions are that the textbooks' questions do not match SBQ. The textbooks' questions are comprehension, knowledge level, and superficial. This is consistent with previous research, too. According to Erden (2020), the questions in the textbooks are not compatible with SBQ. Textbooks do not include questions, such as SBQ, necessary for developing high-level skills (K1zkapan and Nacaroğlu, 2019; Artun et al., 2021). Featuring SBQ in textbooks will reduce a student's need for additional resources (İlhan et al., 2020). This study has also shown that science course gains are compatible with SBQ. The survey conducted by Kizkapan and Nacaroğlu (2019) has stated that SBQ and gains are consistent. Furthermore, it has brought forward that that science gains are the most appropriate course for creating SBQ.

The problem and length of SBQ and the students' prejudice against them have suggested that the interest in science teaching is vanishing. However, according to the study participants, SBQ are highlighted with experiments, and they reflect the events in daily life. Student interest has grown. The survey by Kizkapan and Nacaroğlu (2019) has stated that the SBQ in the central exams address the student in terms of science teaching and attract interest.

Considering the teacher opinions, it can be concluded that SBQ positively and negatively affect student success in science teaching. Furthermore, linking SBQ with daily life positively affects students' success acquiring interpretive and advanced upper skills. SBQ are fundamental in specifying a student's academic success (Erden, 2020). Students developing a positive attitude towards SBQ boost their academic achievement (Kızkapan and Nacaroğlu, 2019). The study has concluded that when students are biased to SBQ, their motivation to the course decreases and this affects the students' achievement negatively. The survey conducted by Güler et al. (2019) stated the questions that push the students into thinking would negatively impact the success.

This study has shown that SBQ improve the interpretation, reading ability, analysis, comprehension skills, problemsolving, and high-level thinking skills of students. When the teachers' views on the most apparent skills development are 
highlighted, it becomes clear that the ability to interpret is the most developed skill. SBQ used in central exams require students to develop high-level skills (Kızkapan and Nacaroğlu, 2019). SBQ measures interpretation, reading comprehension, and analytical skills (Kertil et al., 2021). In the age of globalization and modernization, i.e. the $21^{\text {st }}$ century, HOTS have become the highest cognitive level and ability to connect, manipulate and transform knowledge. It has become an experience to think critically, logically, reflectively, cognitively and creatively during decision-making and problem-solving (Arifin and Ratu, 2018; Yee et al., 2015). If teachers bring realworld occasions into the learning environment, questioningbased learning activities and development of HOTS will be ensured among students (Miri et al., 2007). The use of teaching methods that locate students at center and require a high level of cognitive knowledge assures students' development in HOTS (Mitani, 2021). Collaborative learning-based learning models are highly recommended to improve HOTS abilities among students (Komala et al., 2020).

Science teachers' opinions about the similarities of teaching methods used before and after SBQ are examined. In line with science teachers' views, the narrative approach and the experimental method were similar in both cases. The methods viewed as different are methods for interpretation; they are methods that involve cause and effect relationship, research, and modeling. After using SBQ, differences have occurred in the in-class activities. Teachers appear to be trying to implement a different practice (Kertil et al., 2021).

By analyzing science teachers' opinions about in-service education, it can be stated that teachers do not carry out SBQ preparation work and do not acknowledge themselves as sufficient in this field. They have difficulty understanding the question during the evaluation phase. Teachers need in-service training during the SBQ preparation, implementation, and evaluation stages. Moreover, they will participate in the inservice training that will open in this regard.

In-service training activities should be arranged so that teachers can adapt to new situations more quickly. (Bakırc1 et al., 2014). Erden (2020), in his work, teachers need in-service training in skills-based teaching, and such studies must be organized in each province to help them prepare SBQ.

\section{CONCLUSION AND RECOMMENDATIONS}

The research has observed that subjects covered in the science program do not comply with the SBQ. Science programs and chapter evaluations make use of traditional questions instead of skill-based ones. The questions aim to measure the level of comprehension and skills of theoretical knowledge. SBQ in science demand expertise. It identifies science as one of the most convenient subjects that prepare SBQ.

Despite the idea of decreased interest in science due to challenges in understanding the nature of SBQ, a growth in student interest has been observed because SBQ cover real- life problems and experiments — both positive and negative effects of SBQ on students' success. SBQ positively affect the success level of highly skilled students. However, an adverse effect was observed on the success level of students who bias against SBQ. Furthermore, SBQ are thought to help students improve high-level reading, interpretation, problemsolving, analysis, and comprehension skills. Improvement in interpretation skills has been observed. Before using SBQ, teachers' direct teaching and experiments were the most used methods. Yet, following SBQ, there has been a decline in using other teaching methods. A change shall be implemented in teaching techniques with the introduction of SBQ that target high-level skill sets. Differences in teaching methods, that is, interpretation, cause and effect analysis, research, and demonstration, were monitored when SBQ were introduced.

Another aspect of this study was to gather teachers' opinions on preparation, execution, evaluation, and in-house training needs of SBQ. Science teachers have gaps in practicing SBQ, a situation caused by missing qualifications for the subject matter. Gaps have been identified in the preparation of graphics and visualization. Teachers have difficulties formulating questions and developing time management in the execution of SBQ. The study group has mentioned that they do not have any problems evaluating practices with SBQ. It is vital to provide teachers with necessary up-to-date skill sets and training during their career. Teachers need in-house activities to become more effective in preparing, practicing, and evaluating SBQ. Teachers are willing to join relevant in-house training.

Concerning the discussion and conclusion sections, the researchers of this study recommend that:

a. Course books should be revised to expand SBQ to subject narration coverage

b. To increase student interest and success rate in science, an effective planning in high skill set activities that target SBQ is required. Notably, more weight should be given to in-class activities that support interpretation, reading, and understanding. In addition to primarily used teaching methods of narration and experiment, other methods that back the development of high skill sets should be implemented

c. In-house training should be provided to help teachers gain the skills and knowledge required to prepare, practice and evaluate SBQ.

\section{REFERENCES}

Akçay, B., Akçay, H., \& Kahramanoğlu, E. (2017). Evaluation of elementary science textbooks according to bloom taxonomy. Uludag University Faculty of Education Journal, 30(2), 538-540.

Aksoy, V.C., Şıvkın, S., \& Erdoğan, D.G. (2020). Evaluation of teacher's opinions, according to the relationship between correctly answering PISA style math questions, asked LGS and reading comprehension. Sakarya University Faculty of Education Journal, 20(2), 148-159.

Arifin, A., \& Ratu, N. (2018). Siswa dalam menyelesaikan masalah bangun datar segi empat [Profile higher order thingking skill]. Scientific Journal of Mathematics Education, 5(2), 52-63.

Arıkan, O., \& Kırındı, T. (2020). Analysis of OKS, SBS, TEOG science test questions according to scientific process skills and critical thinking 
skills. Turkish Journal of Primary Education, 5(2), 155-170.

Artun, H., Bakırc1, H., Okur, M., \& Sanca, M. (2021). Evaluation of secondary school skill-based questions in accordance with the restructured bloom technology. YYU Journal of Education Faculty, 18(1), 219-248.

Atılgan, H. (2018). Transition among education levels in Turkey: Pastpresent and a recommended model. Ege Education Journal, 19(1), 1-18.

Ausubel, D.P. (1968). Educational psychology: A cognitive view. New York, United: Holt, Rinehart and Winston.

Baker, C., Wuest, J., \& Stern, P.N. (1992). Method slurring: The grounded theory/phenomenology example. Journal of Advanced Nursing, 17(11), $1355-1360$

Bakırc1, H., Ayvacı, H., \& Yıldız, M. (2014). Opinions and expectations of science teachers regarding in-service educational practices. Amasya Journal of University Faculty of Education, 3(2), 357-383.

Baltac1, A. (2018). A conceptual review of sampling methods and sample size problems in qualitative research. Bitlis Eren University Journal of the Institute of Social Sciences, 7(1), 231-274.

Başkale, H. (2016). Determination of validity, reliability and sample size in qualitative studies. Nine September University Faculty of Nursing Electronic Journal, 9(1), 23-28.

Başol, G. (2019). Eğitimde Ölçme ve Değerlendirme [Measurement and Evaluation in Education]. Ankara: Pegem Publishing.

Batur, Z., Ulutaş, M., \& Beyret, T.N. (2019). Investıgatıon of 2018 Lgs Turkish questions for PISA reading skills objectives. Journal of National Education, 48(1), 595-615.

Bloom, B., Englehart, M. Furst, E., Hill, W., \& Krathwohl, D. (1956). Taxonomy of Educational Objectives: The Classification of Educational Goals. Handbook I: Cognitive Domain. London, United Kingdom: Longmans, Green

Bonal, X., \& Tarabini, A. (2013). The role of PISA in shaping hegemonic educational. Research in Comparative and International Education, $8(3), 335-340$.

Cavanagh, S. (1997). Content analysis: Concepts, methods and applications. Nurse Researcher, 4(3), 5-16.

Çepni, S. (2019). PISA ve TIMMS Mantığını ve Sorularını Anlama [Understanding PISA and TIMMS Logic and Questions]. In: Çepni, S., (Ed.), PISA ve TIMSS Sınavlarında Başarıyı Yakalamak Için Türkiye ne Yapmalı? [What Should Turkey do to Achieve Success in PISA and TIMSS Exams?] Turkey: Pegem Academy. pp. 393-404.

Creswell, J.W. (2002). Educational Research: Planning, Conducting, and Evaluating Quantitative. New Jersey, United States: Prentice Hall.

Creswell, J.W., \& Poth, C.N. (2016). Qualitative Inquiry and Research Design: Choosing among Five Approaches. New York, United States: Sage Publications.

Davis, D. (1990). The Community's Toolbox. Canada: Food and Agriculture Organization of the United Nations.

Downe-Wamboldt, B. (1992). Content analysis: Method, applications, and issues. Health Care for Women International, 13(3), 313-321.

Education Reform Initiative (ERG). (2019). Eğitimin İçeriği, Eğitim Izleme Raporu 2019 [Content of the Training, Training Monitoring Report 2019]. Available from: https://www.egitimreformugirisimi.org/ wpcontent/uploads/2010/01/eir_egitimin_icerigi.pdf

Elo, S., \& Kyngäs, H. (2008). The qualitative content analysis process. Journal of Advanced Nursing, 62(1), 107-115.

Erden, B. (2020). Teachers' views related to skill-based questions in Turkish, mathematics and science lessons. AJER-Academia Journal of Educational Research, 5(2), 285.

Fer, S. (2014). Öğrenme öğretme kuram ve yaklaşımlarına giriş [Introduction to learning and teaching theories and approaches]. Ö̆grenme Ögretme Kuram ve Yaklaşımlarl [Learning and Teaching Theories and Approaches]. New York: Memoir Publishing. pp. 1-11.

Fidan, M. (2018). Analysis of secondary school student's views on the design of Turkish lesson books. Bayterek International Journal of Academic Research, 1(2), 178-189.

Güler, H.K., \& Ülger, B. (2018). PISA, TIMSS ve TEOG sınavlarının temele aldığı ögrenme kuramları [The learning theories on which PISA, TIMSS and TEOG exams are based]. In: Çepni, S., (Ed.), PISA ve TIMSS Mantı̆̆ını ve Sorularını Anlama içinde [Understanding PISA and TIMSS Logic and Questions]. Turkey: Pegem Publishing. pp. 114-115.

Güler, M., Arslan, Z., \& Çelik, D. (2018). Mathematics teachers' views on the 2018 entrance exam for high schools. Yüzüncüyll University Faculty of Education Journal, 16(1), 337-363.

Gün, M., \& Kaya, İ. (2018). Evaluation of Turkish teachers' relationships between the revolved secondary school transition system. International Journal of Social Science Number, 71, 67-79.

Gür, B.S., Çelik, Z., \& Ozoğlu, M. (2012). Policy options for Turkey: A critique of the interpretation and. Journal of Education Policy, 27(1), $1-21$

Harus, E.B., \& Davidovitch, N. (2019). The GEMS Exams in Israel-between center and periphery. International Education Studies, 12(10), 9-21.

Hsieh, H.F., \& Shannon, S. (2005). Three approaches to qualitative content analysis. Qualitative Health Research, 15(9), 1277-1288.

İlhan, A., Korkmaz, E., \& Tutak, T. (2020). Evaluation of secondary school mathematics textbooks by mathematics teachers. European Journal of Science and Technology, 18, 123.

Kertil, M., Gülbağcı Dede, H., \& Ulusoy, E. (2021). Skill-based mathematics questions: What do middle school mathematics teachers think about and how do they implement them? Turkish Journal of Computer and Mathematics Education (TURCOMAT), 12(1), 151-186.

Kızkapan, O., \& Nacaroğlu, O. (2019). Science teachers' opinions about central exams (Lgs). Nevşehir Hacı Bektaş Veli University SBE Journal, 9(2), 713.

Komala, R., Lestari, D., \& Ichsan, I. (2020). Group investigation model in environmental learning: An effect for students' higher order thinking skills. Universal Journal of Educational Research, 8(4A), 9-14.

Kutlu, Ö. (2018). Ölçme ve Değerlendirmede Değişim Zamanı [Time for Change in Measurement and Evaluation]. Liberty. Available from: https://www.hurriyet.com.tr/egitim/olcme-degerlendirmede-degisimzamani-40790292

Levine, D. (1995). Building a vision of curriculum reform. In: Levine, D., Lowe R., Peterson, B., \& Tenorio, R., (Eds.), Rethinking Schools: An Agenda for Change. New York, United States: The New Press. pp. 5260.

Maggs-Rapport, F. (2000). Combining methodological approaches in research: Ethnography and interpretive phenomenology. Journal of Advanced Nursing, 31(1), 219-225.

Mayring, P. (2004). Qualitative content analysis. A Companion to Qualitative Research, 1(2), 159-176.

Ministry of National Education (MoNE). (2005). PISA 2003 Projesi Ulusal Nihai Rapor [PISA 2003 Project National Final Report]. Available from: http://www.pisa.meb.gov.tr/wp-content/uploads/2013/07/pisa2003-ulusal-nihai-rapor.pdf

Ministry of National Education (MoNE). (2015). Milli Eğitim Bakanlığ 2015-2019 Stratejik Plant. [Ministry of National Education 2015-2019 Strategic Plan]. Available from: http://www.sgb.meb.gov.tr/meb_iys dosyalar/2015_09/10052958_10.09.2015sp17.15imzasz.pdf

Ministry of National Education (MoNE). (2017). Ministry of National Education, Directorate of Training and Training. Available from: https://www.ttkb.meb.gov.tr/meb_iys_dosyalar/2017_07/18160003 basin_aciklamasi-program.pdf

Ministry of National Education (MoNE). (2018a). 2023 Eğitim Vizyonu [2023 Education Vision]. Available from: http://www.2023vizyonu. meb.gov.tr/doc/2023 egitim vizyonu.pdf

Ministry of National Education (MoNE). (2018b). Liselere Geçiş Sistemi Merkezi Sinavla Yerleşen Ögrenci Performansı, Eğitim Analiz ve Değerlendirme Raporlart Serisi, 3 [Student Performance in the Transition System to High Schools Through the Central Exam, Education Analysis and Evaluation Reports Series, 3]. Available from: https://www.meb.gov.tr/meb_iys_dosyalar/2018_12/17094056_2018_ lgs_rapor.pdf

Ministry of National Education (MoNE). (2018c). Milli Eğitim Bakanlığı Ortaögretime Geçiş Yönergesi [Ministry of National Education Directive on Transition to Secondary Education]. Available from: https://www. meb.gov.tr/meb iys dosyalar/2018 03/26191912 yonerge.pdf

Ministry of National Education (MoNE). (2019a). PISA 2018 Ulusal ön Raporu. Eğitim Analiz ve Değerlendirme Raporları Serisi, 10 [PISA 2018 National Preliminary Report. Education Analysis and Evaluation Reports Series, 10]. Available from: https://www.meb.gov.tr/meb iys dosyalar/2019_12/03105347_pisa_2018_turkey_on_raporu.pdf

Ministry of National Education (MoNE). (2019b). Ortaöğretim Kurumlarına 
Ilişsin Merkezi Sinav, Eğitim Analiz ve Değerlendirme Raporlart Serisi, 7 [Central Examination for Secondary Education Institutions, Education Analysis and Evaluation Reports Series, 7]. Available from: https://www.meb.gov.tr/meb_iys_dosyalar/2019_06/24094730_2019_ ortaogretim kurumlarina iliskin merkezi_sinav.pdf

Ministry of National Education (MoNE). (2019c). Sinavla Öğrenci Alacak Ortaöğretim Kurumlarina Ilişkin Merkezî Sinav Başvuru ve Uygulama Kilavuzu [Central Exam Application and Application Guide for Secondary Education Institutions that Will Accept Students by Exam]. Available from: http://www.mevzuat.meb.gov.tr/dosyalar/2009.pdf

Miri, B., David, B.C., \& Uri, Z. (2007). Purposely teaching for the promotion of higher-order thinking skills: A case of critical thinking. Research in Science Education, 37, 353-369.

Mitani, H. (2021). Test score gaps in higher order thinking skills: Exploring instructional practices to improve the skills and narrow the gaps. AERA Open, 7(1), 1-23.

OECD. (2019). PISA 2018 Assessment and Analytical Framework. United Kingdom, France: OECD Publishing.

Patton, M.Q. (2014). Qualitative Research and Evaluation Methods: Integrating Theory and Practice. New York, United States: Sage publications.

Pyett, P.M. (2003). Validation of qualitative research in the "Real World." Qualitative Health Research, 13(8), 1170-1179.

Schreier, M. (2012). Qualitative Content Analysis in Practice. New York,
United States: Sage.

Selçuk, Z. (2019). 2021 PISA'da Çok Daha Iyi Noktaya Geleceğiz [We Will Come to a Much Better Point in 2021 PISA]. Available from: http://www. meb.gov.tr/2021-pisada-cok-daha-iyi-noktaya-gelecegiz/haber/19944/tr

Sivkın,S., Aksoy, V. C., \& Erdoğan, D. G. (2020). Evaluation of teacher's opinions, according tothe relationship between correctly answering PISA style math questions, askedLGS and reading comprehension. Sakarya University Faculty of EducationJournal, 20(2), 148-159.

Woessmann, L. (2018). Central exit exams improve student outcomes. IZA World of Labor, 419, 1-10. Available from: https://www.wol.iza org/uploads/articles/419/pdfs/central-exit-exams-improve-studentoutcomes.pdf

Wolcott, H. (1975). Criteria for an Ethnographic Approach to Research in Schools. Human Organizatıon, 34(2), 111-127. Available from: https:// www.jstor.org/stable/44125322

Yee, M., Yunos, J., Othman, W., Hassan, R., Tee, T., \& Mohamad, M. (2015). Disparity of learning styles and high order thinking skills among tecnical students. Procedia-Social Behavioral Sciences, 204, 143-152.

Yıldırım, A., \& Şimşek, H. (2018). Sosyal Bilimlerde Nitel Araştırma Yöntemleri [Qualitative Research Methods in Social Sciences]. Seçkin Yayıncilik.

Zorluoğlu, S.L., Olgun, M., \& Kızılaslan, A. (2020). Content analysis of researches on the revised bloom taxonomy related to the science in turkey. Trakya Education Journal, 10(1), 23-32. 